\title{
Body axis elongation and ciliary function in zebrafish require Noni a novel ciliary protein
}

\author{
J Jerber ${ }^{*}$, CB Chhin, SF Soulavie, BD Baas, VC Vesque, DB Durand, TJ Thomas \\ From First International Cilia in Development and Disease Scientific Conference (2012) \\ London, UK. 16-18 May 2012
}

Cilia are highly conserved structures found from protozoa to mammals where they play major functions in motility and sensation. Ciliary dysfunction leads to a variety of human genetic diseases called ciliopathies. RFX transcription factors are key players in regulating genes involved in cilia assembly from C. elegans to mammals. Using a genomic screen to identify targets of RFX, we selected a novel gene, noni, potentially implicated in cilia biology. No known function has been described for this gene, which is highly conserved and specific of ciliated species. We show that noni expression is increased during in vitro induced ciliogenesis in primary mouse ependymal cell culture and that Noni localizes to cilia from Drosophila to mammals. We performed functional analysis in zebrafish and show that loss of function of noni mimics human symptoms associated with ciliopathies such as kidney cysts and randomized left right patterning. We demonstrate that Noni is necessary for cilia function. Indeed, we show that nodal flow is impaired in Kupffer's vesicle of noni morphants. Moreover, noni morphants have defects in body axis elongation and present impaired basal body positioning in the floor plate suggesting that noni is implicated in planar cell polarity (PCP). To test this hypothesis, we are currently analysing genetic interaction with known PCP components associated with cilia function. In conclusion, we have identified a novel conserved ciliary gene noni, which is necessary for ciliary function and planar cell polarity in zebrafish.

Published: 16 November 2012

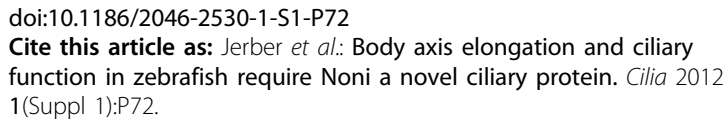

* Correspondence: julie.jerber@univ-lyon1.fr

University of Lyon, France
Submit your next manuscript to BioMed Central and take full advantage of:

- Convenient online submission

- Thorough peer review

- No space constraints or color figure charges

- Immediate publication on acceptance

- Inclusion in PubMed, CAS, Scopus and Google Scholar

- Research which is freely available for redistribution
C Biomed Central
C Biomed Central

C 2012 Jerber et al; licensee BioMed Central Ltd. This is an Open Access article distributed under the terms of the Creative Commons Attribution License (http://creativecommons.org/licenses/by/2.0), which permits unrestricted use, distribution, and reproduction in any medium, provided the original work is properly cited. 